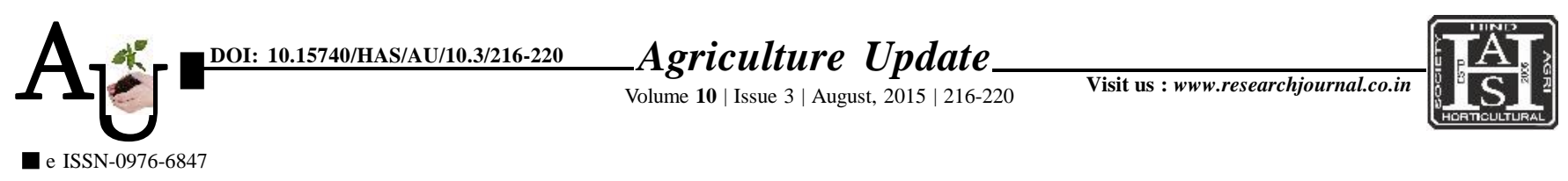

\title{
Rевевсн автіск: Vegetable cultivation in Pathanamthitta district of Kerala - A constraint analysis
}

Article Chronicle:
Received :
13.04.2015;
Revised :
06.07.2015;
Accepted :
07.08.2015

KEY Words :

Vegetable cultivation, Constraints

Author for correspondence :

\section{A. SAJEENA}

Agricultural Research

Station (K.A.U.),

Thiruvalla, PATHANAMTHITTA

(KERALA) INDIA

Email: sajeenamanjima@ gmail.com

See end of the article for

authors' affiliations

\author{
A. SAJEENA, JESSY M. KURIAKOSE, V.R. SHAJAN, G. JAYAKUMAR AND \\ SOSAMMA CHERIAN
}

SUMMARY : A study was conducted during 2012-13 among the vegetable farmers of Pathanamthitta district to analyze the problems and prospects of vegetable cultivation. A total of 402 progressive vegetables farmers were identified in consultation with the Agricultural Officers of State Department of Agriculture. Two stage stratified random sampling was adopted. The various socio-personal and communication perspectives analyzed during the study revealed that 83 per cent of the farmers fell in the age range of 46 years and above and that 76 per cent had an education background of upto primary level only. The family status of majority of the farmers fell to the group of nuclear family (74\%) with a maximum of four members, which also reveals the changing system of family relations in the society. The work also throws light on a major issue faced presently in agriculture, which is the dependence on external labour. Crop loss due to the attack of diseases and pests has been identified as the most important problem faced in vegetable cultivation as opined by 83.3 per cent of the surveyed farmers. The study clearly demonstrated the lacuna between development of scientific cultivation practices and its adoption by the farmers, as only 12.9 to 46.3 per cent of the total respondents adopted scientific practices of vegetable cultivation. Thus, the study necessitates the need for bridging the gap between technology creation and technology adoption at farmer's level. The measures to be adopted for making vegetable cultivation a profitable venture are adoption of scientific cultivation practices; general awareness on pest management, soil test based fertilizer usage as well as forecasting natural disasters. Encouragement of the progressive farmers through awards and other recognitions as well as assuring reasonable sale price for agricultural produce can attract younger generation to take up agriculture as a profession thereby reducing the dependence of our state on others states for food and other commodities.

How to cite this article : Sajeena, A., Kuriakose, Jessy M., Shajan, V.R., Jayakumar, G. and Cherian, Sosamma (2015). Vegetable cultivation in Pathanamthitta district of Kerala - A constraint analysis. Agric. Update, 10(3): 216-220. 